\title{
After the Peasants' War: Barbara (Schweikart) von Fuchstein Fights for Her Property
}

\author{
CHRISTOPHER OCKER
}

San Francisco Theological Seminary and the Graduate Theological Union at Berkeley

Historians are only beginning to appreciate fully the political and social impact of the aftermath of the German Peasants' War. The case of Barbara (Schweikart) von Fuchstein, widow of Sebastian von Fuchstein, a Kaufbeuren lawyer suspected of Anabaptism and exiled at the end of the war, sheds light on the role of middle-rank nobility in the process of post-war reordering. Her eventual success in a conflict with her violent cousin, Ulrich Schweikert, a knight in the service of the Abbot of Kempten, draws attention to middle-rank competition in the Upper Allgäu, where historians have emphasized the tenacity of peasants and the long-term winnings of princes. Her case also illustrates the flux of religious identities at ground level in the early Reformation, among lay people whose interest in the religious controversy was secondary to, perhaps inseparable from, family business.

Les historiens commencent à peine à mieux comprendre l'impact politique et social des suites de la Guerre des Paysans en Allemagne. Le cas de Barbara (Schweikart) von Fuchstein, veuve de Sebastian von Fuchstein, un avocat de Kaufbeuren suspecté d'être anabaptiste et exilé à la fin de la guerre, met en lumière le rôle de la petite noblesse dans la réorganisation d'après-guerre. En effet, le succès remporté par Barbara (Schweikart) von Fuchstein contre son agressif cousin, Ulrich Schweikart, chevalier au service de l'abbé de Kempten, attire notre attention sur la compétition se déroulant au sein de cette noblesse dans la région de l'Oberallgaü, tandis que les historiens ont par ailleurs souligné la ténacité des paysans et les gains à long terme des princes. Ce cas illustre également le caractère changeant des identités religieuses dans les populations des débuts de la Réforme, tels les laïcs ayant moins d'intérêt pour les controverses religieuses que pour leurs affaires familiales, voire subordonnant les premières aux secondes.

$\mathrm{B}_{\mathrm{t}}^{\mathrm{a}}$ arbara Schweikart was a woman of low-noble rank born to the family of he knights of Westerried, a small castle near Kempten. With her husband, Sebastian von Fuchstein, a lawyer in the town's service, she lived in Kaufbeuren, an imperial city in the rolling hills of the Upper Allgäu northwest of Lake Constance and not far from the Alps. When the Peasants' War came to Barbara's town in 1525 , she watched the city's councillors try to navigate a safe course through the rebellion, and she watched the conflict entangle her husband, encumbering both their reputations. Historians have known about Sebastian since the early nineteenth century, although he has sometimes been confused with Duke Ulrich of Württemberg's chancellor, Johann von Fuchstein, a key 
figure in the exiled duke's attempt to use the peasant turmoil to reclaim his duchy, and Sebastian was even erroneously named as the author of the Twelve Articles of Upper Swabia. ${ }^{1}$ Scholars have completely ignored Barbara, which is a shame. ${ }^{2}$ Sebastian died after the war, leaving Barbara to defend her estate, while a knight, her kinsman, who had helped put down the revolt, tightened his grip on properties he had taken during and just after the conflict.

Historians are only beginning to appreciate fully the political and social impact of the aftermath of the German Peasants' War, when some nobility "reverted to feuding with a vengeance" and rich peasants tried to stabilize relations with nobles. ${ }^{3}$ As for women, research has tended to focus on town dwellers, nuns, women of high-noble rank, or state-building, alternatively stressing the (often negative) impact of Protestant reform on women's economic participation and social freedom, their escape from patriarchy and cultural productivity in monasteries, their role in high politics to promote or

1. Joseph Edmund Jörg, Deutschland in der Revolutionsperiode von 1522 bis 1526 (Freiburg i. Briesgau: Herder, 1851), 178-83, takes the Kaufbeuren Fuchstein to be one and the same as Johann von Fuchstein, Ulrich's chancellor. Jörg alleges that Johann moved to Kaufbeuren when Ulrich's plans for an invasion of Württemberg during the Peasants' War fell apart, wrongly taking references to Kaufbeuren's "Dr. Fuchsteiner" as references to Johann. Arguing then from a pile of circumstantial evidence, he claims that Johann von Fuchstein was in fact the author of the Twelve Articles. Wilhelm Zimmermann picked up and embellished Jörg's misattribution, saying that Johann von Fuchstein came to Kaufbeuren as a preacher, writer, and chancellor of the peasants, gaining control of one of the city's church pulpits and preaching in German. Felix Stieve disambiguated the two Fuchsteins, Sebastian and Johann, but he clung to the idea that a Fuchstein wrote the Twelve Articles: Sebastian von Fuchstein, he said, was the author of the Bavarian version of the Twelve Articles. See Felix Stieve, Die Reichsstadt Kaufbeuren und die baierische Restaurationspolitik (Munich: Mattheus Rieger, 1870), 7n1, and Alfred Stern's review of this book in Göttingiche gelehrte Anzeigen 132(1870): 386-90. For the actual origin of the Twelve Articles, see Peter Blickle, "Nochmals zur Entstehung der Zwölf Artikel im Bauernkrieg," Bauer, Reich und Reformation, ed. Peter Blickle (Stuttgart: Ulmer, 1982), 286-308.

2. I pointed to her case in "Between the Old Faith and the New: Spiritual Loss in Reformation Germany," Enduring Loss in Early Modern Germany: Cross-Disciplinary Perspectives, ed. Lynn Tatlock (Leiden: Brill, 2010), 231-58, 234-35. This present article gives a fuller account.

3. Hillay Zmora, State and Nobility in Early Modern Germany (Cambridge: Cambridge University Press, 2003), 105; Govind Sreenivasan, The Peasants of Ottobeuren, 1487-1726 (Cambridge: Cambridge University Press, 2004), 30-41. Peter Blickle called attention to the importance of the aftermath of the war in his own preliminary comments on the war's aftermath: Peter Blickle, The Revolution of 1525: The German Peasants' War from a New Perspective, trans. T. A. Brady and H. C. E. Midelfort (Baltimore: Johns Hopkins University Press, 1991), 165-69. 
resist Lutheran reform, the place of virginity and chastity in social discipline and state-building, and the constructs of gender related to these things. ${ }^{4}$ In all this, the tendency is to look up toward women of very high social rank, or in toward women in religious vocations, or out toward the social structures and conceptualizations that conditioned women's opportunities. However valuable all of this clearly is, ordinary women responding to the religious controversy as they met everyday challenges have been largely ignored. Tom Scott has offered one of very few exceptions to this rule, in an exemplary study of groups of women physically defending local preachers in the early stages of the Peasants' War. ${ }^{5}$ Barbara's case draws attention to a woman of middle or perhaps

4. From a spectacularly thriving field, I mention a small selection of notable and representative works relating to Germany. In general, Merry Wiesner-Hanks, "Reflections on a Quarter Century of Research on Women," History Has Many Voices: Sixteenth Century Essays and Studies, ed. Lee Palmer Wandel (Kirksville: Truman State University Press, 2003), 93-112; Anne Conrad, "Vom Evangelium zur Ehe. Frauen in der Zeit der Reformation," Frauen und Reformation. Handlungsfelder - Rollenmuster Engagement, ed. Martina Schattkowsky (Leipzig: Leipziger Universitätsverlag, 2016), 39-53. For women in cities, Lyndal Roper, Holy Household: Women and Morals in Reformation Augsburg (Oxford: Clarendon Press, 1989); Merry Wiesner, Working Women in Renaissance Germany (New Brunswick: Rutgers University Press, 1986). For women in monasticism, Ulrike Strasser, State of Virginity: Gender, Religion, and Politics in an Early Modern Catholic State (Ann Arbor: University of Michigan Press, 2004); Corine Schleif and Volker Schier, Katerina's Windows: Donation and Devotion, Art and Music as Heard and Seen through the Writings of a Brigittine Nun (University Park: Pennsylvania State University Press, 2009); the essays by Ral Frassek, Anke Fröhlich-Schauseil, Sabine Zinsmeyer, and Jasmin Irmgard Hoven-Hacker in Frauen und Reformation, 255-39; and the observations of Simone Laqua-O'Donnell, Women and the Counter-Reformation in Early Modern Münster (Oxford: Oxford University Press, 2014), 20-22, for the study of early modern women's monasticism beyond Germany. For Protestant women, Kirsi Stjerna, Women and the Reformation (Oxford: Blackwell, 2009); Antje Rüttgardt, Klosteraustritte in der frühen Reformation (Heidelberg: Verein für Reformationsgeschichte, 2007); Elsie Anne McKee, Katharina Schütz Zell, 2 vols. (Leiden: Brill, 1999); and the entire collection of essays in Frauen und Reformation, mentioned above. For the role women of princely rank played in confessional statebuilding, stressing their especially autonomous role, see Heide Wunder, "Fürstinnen und Konfessionen im 16. Jahrhundert," Fürstinnen und Konfession. Beiträge hochadliger Frauen zur Religionspolitik und Bekenntnisbildung, ed. Daniel Gehrt and Vera von der Osten-Sacken (Göttingen: Vandenhoeck und Ruprecht, 2015), 15-34, and all the essays of this superb volume; and Jill Bepler, "Enduring Loss and Memorializing Women: The Cultural Role of Dynastic Widows in Early Modern Germany," in Enduring Loss in Early Modern Germany: Cross-Disciplinary Perspectives, ed. Lynn Tatlock (Leiden: Brill, 2010), 133-60.

5. Tom Scott, "The Collective Response of Women to Early Reformation Preaching: Four Small Communities and their Preachers Compared," Archiv für Reformationsgeschichte 102 (2011): 7-32, 
upper-middle status, displaying her tenacity in the sequel to armed conflict. Her case also illustrates the flux of religious identities at ground level in the early Reformation, among people whose interest in the religious controversy was secondary to, perhaps inseparable from, family business.

\section{How the revolt came to Kaufbeuren}

As in other cities, so in Kaufbeuren in early 1525, local religious unrest, encouraged by a city preacher, coincided with the peasant uprising. ${ }^{6}$ Jakob Lutzenberger, a chaplain in Kaufbeuren's Hospital of the Holy Spirit, had been preaching against the Mass for some months, when a sermon he gave in the parish church of St. Martin on the Feast of Epiphany (6 January) incited an armed mob before the town hall to demand a public disputation. ${ }^{7}$ After consulting with their peers in Augsburg, Kempten, and Memmingen, the council responded with strategic prevarication. They scheduled a disputation on religion later that month. Barbara's husband was chosen, with the Kaufbeuren physician Ivo Stigl, to preside. It took place over two days from 31 January to

reprinted in Tom Scott, The Early Reformation in Germany: Between Secular Impact and Radical Vision (Burlington: Ashgate, 2013), 117-41. For challenges to the study of women in the Peasants' War, see Franziska Neumann, "Der selektive Blick. Frauen im Bauernkrieg zwischen Frauen- und Geschlechtergeschichte," Frauen und Reformation, 153-70.

6. Some two dozen cities that allied with the peasants are conveniently noted in a map by Manfred Scheuch, Historischer Atlas Deutschland (Munich: C. H. Beck, 1997), 55, and reproduced online by Barbara Stollberg-Rilinger (https://www.uni-muenster.de/FNZ-Online/politstrukturen/reformation/quellen/ bauernkrieg.htm, accessed 5 September 2016). The German Peasants' War: A History in Documents, trans. and ed. Tom Scott and Robert Scribner (Amherst, NY: Humanities Press, 1991), 1-64, remains the best compact survey of the war in English. For representative documents regarding cities and the uprising, see pp. 170-96.

7. Justus Maurer, Prediger im Bauernkrieg (Stuttgart: Calwer, 1979), 399-401. See also Peter Blickle, “Urteilen über den Glauben. Die Religionsgespräche in Kaufbeuren und Memmingen 1525," Außenseiter zwischen Mittelalter und Neuzeit: Festschrift für Hans-Jürgen Goertz zum 60. Geburtstag, ed. Nobert Fischer and Marion Kobelt-Groch (Leiden: Brill, 1997), 65-80; Christopher Close, The Negotiated Reformation: Imperial Cities and the Politics of Urban Reform, 1525-1550 (Cambridge: Cambridge University Press, 2009), 38-43; Gudrun Litz, Die reformatorische Bilderfrage in den schwäbischen Reichsstädten (Tübingen: Mohr Siebeck, 2007), 233-36; Thomas Pfundner, "Das Memminger und Kaufbeurer Religionsgespräch von 1525," Memminger Geschichtsblätter (1991-92): 23-66. 
1 February. ${ }^{8}$ Proceedings had barely been opened when a priest from nearby Aitrang, Nikolaus Schwicker, protested the city council's legitimacy, noting that this business belonged to a general church council and the bishop of Augsburg's jurisdiction. When he failed to scuttle the event, he stormed out with several sympathizers. Lutzenberger, however, stayed; he offered a prayer, and then explained the seven articles he had proposed for debate, followed by a point-by-point dialogue with the priests who remained. ${ }^{9}$ The absent recusants must have felt railroaded. Lutzenberger's articles struck decidedly Lutheran and Zwinglian notes; yet the council responded cautiously to Lutzenberger's solo performance, demanding that only the gospel, proved by Scripture, was to be preached in the city. Individual laity could choose whether to visit masses and vigils. No preacher or priest was allowed to defame another. ${ }^{10}$ This outcome hardly counted as a resounding endorsement for followers of Luther or Zwingli; the appeal to gospel preaching was arguably, at least partially, consistent with the recess of the diet of Nuremberg in $1524 .{ }^{11}$ In the next months, Kaufbeuren requested theological advice on church practices from Constance, Ulm, and Augsburg (at a time when none of them had thrown full weight against the priesthood), then opted for the safest course and did nothing. ${ }^{12}$ Significantly, the city took no actions against the Mass or priests, in sharp contrast with the outcome of a similar disputation at Memmingen, which served as Kaufbeuren's immediate model. ${ }^{13}$ Memmingen's disputation ended with a temporary prohibition of the Mass and other ceremonies. ${ }^{14}$

When the peasants' revolt came to the neighbourhood, prevaricating got a lot trickier. In February 1525, peasants and town dwellers from communities across the Allgäu gathered in several popular assemblies to renegotiate their rights, rents, dues, tithes, taxes, and obligations with the abbot of Kempten

8. For this and the following, Karl Alt, Reformation und Gegenreformation in der freien Reichsstadt Kaufbeuren (Munich: Christian Kaiser, 1932), 22-28; Pfundner, 28-31; Blickle, “Urteilen," 76. Stieve, in Die Reichsstadt Kaufbeuren (6-7), gave the date incorrectly as 25 January 1525.

9. For this and the following, Alt, 25-26.

10. Alt, 27-28.

11. Deutsche Reichstagsakten, jüngere Reihe (hereafter DRA) (Gotha: Perthes, 1893-2015), 21 vols., 4:603-05. DRA 5/6:55.

12. Alt, 28. Stieve, 6-7.

13. Close, 42-43.

14. Pfundner, 27. 
and other lords. Villagers of Upper Swabia also assembled near Kaufbeuren on Candlemass (2 February) 1525 and presented eleven articles to the city council, demanding free fishing, hunting, and lumbering, freedom of movement, a release from certain feudal obligations, and other things fairly typical of grievances in this and recent years, hoping to enlist the council for their cause. ${ }^{15}$ Rather than turn them down, the city quickly sent a report to the Swabian League, documenting their predicament: that the council had to indulge peasants, who were free to come and go from the community, in order to maintain peace within their small town, susceptible to internal unrest as it had just proved to be a few weeks before, and the encamped peasants could easily disrupt its market and water supply. But the Swabian League was counting partisans. It took a callous view of the city's problem. It concluded that the town was divided between the League and peasant supporters. ${ }^{16}$

Finding no relief from their princes, the peasants of Upper Swabia joined forces with bands from Lake Constance and Lower Swabia at Memmingen in early March to create a short-lived Christian Union (it was disbanded 27 April), a formation parallel to a similar Christian Union formed in the Hegau to the west. ${ }^{17}$ As in peasant risings elsewhere over the previous fall and winter, their combined forces included a small but noticeable number of priests, serving as

15. The original articles, to my knowledge, do not survive. Wilhelm Zimmermann, Geschichte des großen Bauernkrieges (Naunhof and Leipzig: F. W. Hendel Verlag, 1939), 224, relied on Johann Christoph von Schmid's eighteenth-century transcriptions. These are likely to be found today in Stuttgart, Württembergische Landesarchiv, J 9 Bü 13 and Bü 13a, but I have not had opportunity to check them. Franz Ludwig Baumann, citing Zimmermann, believed the articles presupposed an appeal to divine law ("welche [Artikeln] unverkennbar das göttliche Recht voraussetzen ..."), in Die oberschwäbischen Bauern im März 1525 und die zwölf Artikel (Kempten: Joseph Rösel, 1871), 6. But Baumann’s own source, the report of Wolfgang Ludwig Hörmann's "Sammlung der fürnehmsten Merkwürdigkeiten," makes no allusion to divine law or Scripture; see Franz Ludwig Baumann, Quellen zur Geschichte des Bauernkriegs in Oberschwaben (Tübingen: Literarischer Verein, 1876), 359, with 365. Alt, citing Baumann, claims that the Eleven Articles "appeal to the divine law" (Alt, 33). The Eleven Articles did not appeal to the Word of God or divine law, or discuss the congregation's right to appoint pastors-the most explicitly religious elements of the Twelve Articles.

16. Zimmermann, 224, from two letters of the council in the Kaufbeuren Archiv per Schmid.

17. Scott and Scribner, eds., 27, 128-35. Zimmermann, 217-33, as corrected by Günther Franz, Der deutsche Bauernkrieg, 8th ed. (Homburg: Herman Gentner, 1969), 127-40. 
both preachers and captains. ${ }^{18}$ A broad evangelicalism (appeals to the Word of God) buttressed their most startling request, that heritable bondage be abolished because it contradicted the freedom taught by Scripture-as the third of the famous Twelve Articles, published by the Swabian Peasants and copied by rebels all over Germany, said. ${ }^{19}$ From March to July, the southwest German peasant armies marched about the region, compelled villages and towns to join them, destroyed and pillaged properties of princes, prelates, and monasteries, and were finally vanquished that summer in several tidy bloodbaths by the Swabian League, whose troops were fortified by well-practised veterans returning from the war between Charles V and Francis I, decommissioned in Italy at the end of February, just as the Upper Swabian peasants were beginning to organize themselves.

Just after the three Upper Swabian armies confederated as the Christian Union at Memmingen in early March, it was said that some seven hundred peasants of the abbots of Irsee and Kempten, the bishop of Augsburg, and the count of Montfort made a pact at Kaufbeuren to withstand a Bavarian attack, at the first sound of church bells announcing war on the Bavarian side of the Lech river, just a few kilometers east of Kaufbeuren. The same report, by the duke of Bavaria's captain, alleged that a certain "Fursteiner erected a preachership in the church and wants to read out the Word of God in German."20 Two weeks later, Doctor "Fuchstainer" and the Kaufbeuren burgomaster Blasy Hannolt appear among ten mediators put forward by the Christian Union to negotiate with the Swabian League at Ulm. ${ }^{21}$ The maelstrom swirled near Kaufbeuren, and Barbara's husband, Sebastian, found himself near its centre.

When mediation failed, the city prepared for all eventualities at once. They fortified the walls. They formed an urban militia (it was led by Fuchstein's co-president of the January disputation, the physician Ivo Stigel). They

18. Claudia Ulbrich, "Geistliche im Widerstand? Versuch einer Quantifizierung am Beispiel des Sundgaus," Zugänge zur bäuerlichen Reformation, ed. Peter Blickle (Zurich: Chronos, 1987), 237-56.

19. Scott and Scribner, eds., 254-55.

20. Reported on 9 March 1525 by the Bavarian captain of Schongau, Sigmund von Pfeffenhausen. Jörg, 178. All English translations are my own unless otherwise noted.

21. Wilhelm Vogt, "Die Correspondenz des schwäbischen Bundeshauptmanns Ulrich von Augsburg aus den Jahren 1524, 1525 und 1526," Zeitschrift des historischen Vereins für Schwaben und Neuburg 6 (1879): 280-404, 382 no. 140 (24 and 25 March 1525, Hauptmann Ulrich Artz to the burgomasters Ulrich Rehlinger and Hieronymus Imhof of Augsburg). 
communicated constantly with the Swabian League, but they also negotiated with the Baldringen peasants' army, encamped nearby at Matzensies and Angelberg, while both the Swabian League and the peasants threatened to attack the town. ${ }^{22}$ They helped the abbot of Kempten try to recover properties lost to the peasants of Günzburg, then helped peasants try to leverage looted property for a truce of peasant armies with the Swabian League..$^{23}$ Soon, the Bavarian duke's forces were burning villages (Buchloe and Widergeltingen) just north of Kaufbeuren. The abbot and cloister of Isny, which the peasants had destroyed, took refuge in the city on 6 May. The city paid a hefty ransom of 130 gulden to the peasants to leave the Isny abbot, his monks, and Kaufbeuren unmolested. $^{24}$

Relief, if we can call it that, came in mid-May, when a regiment of the Swabian League's infantry under the captain Hans Schnitzer took up quarters in Kaufbeuren for six weeks, through the month of June. This ended the town's need to juggle a present threat of rebels with a future threat of retribution, but it also exposed other sensitivities. The town council now carefully avoided appearances of heresy and rebellion, and prohibited all private assemblies. But then, on the morning of the feast of Corpus Christi, when people were preparing for the annual procession, the new burgomaster, Matheis Klammer, received the report that a dozen burghers had assembled at the home of Sebastian von Fuchstein, that is, in Barbara Schweikart's house. Klammer stormed into the building and accused Fuchstein of planning an urban rebellion. That same day he also warned the town's two priests to preach nichz aufrurigs in their feast day sermons. By Klammer's own account, the two priests complied, yet they ran from the city that evening. Fuchstein himself left town on the following Friday. And the city council prohibited any of them to return, while also, for good measure, expelling the two common-law wives (köchene oder weiber) of the two priests. ${ }^{25}$ Fuchstein claimed that Kaufbeuren later readmitted him, and before the year was out he tried to clear his name before the Swabian League, claiming

\section{Alt, 36-37.}

23. Baumann, Akten zur Geschichte, 361-62. Alt, 38-39 for this and the following.

24. Alt, 39-40.

25. Wilhelm Vogt, "Die Correspondenz des schwäbischen Bundeshauptmanns Ulrich von Augsburg aus den Jahren 1524, 1525 und 1526," Zeitschrift des historischen Vereins für Schwaben und Neuburg 10 (1883): 1-300, 24-26 no. 529, 23 June 1525, Council of Kaufbeuren to Council of Augsburg. 
that the public shame of the accusation of rebellion had forced him to flee. ${ }^{26}$ Barbara left with him. Whether they ever returned to Kaufbeuren is unknown. Soon after the war, Sebastian died, and Barbara had settled in Memmingen.

We know that in Bavarian court circles, Barbara's husband was considered a heretic and a peasant leader ${ }^{27}$ But although it is clear that the religious controversy helped to shape an extraordinarily dynamic environment of discontent before and during the Peasants' War, Tom Scott rightly cautions the historian not to expect narrow correlations between doctrine and revolt. ${ }^{28}$ Nothing in Fuchstein's actions, or in the deeds of Kaufbeuren's city council, some of which he probably recommended, was wildly inconsistent with the recess of the 1524 Nuremberg diet, nor did it contravene an urban political culture that routinely, of necessity, preferred compromise to violent confrontation. "In a walled city, where there was no secure place of refuge from internal rebellion, it was probably not difficult to convince all but the most militant Catholics that to fail to yield some would mean to lose all." ${ }^{29}$ Extraordinarily few cities had taken measures to end the Mass or reorganize church properties before the Peasants' War, which is to say that there was almost no such thing as an evangelical church, town, or territory when Barbara and her husband were expelled.

By mid-July, the captain of the Swabian League, Count Georg Truchsess von Waldburg, had put down all the rebels of Upper Swabia. The disbursing,

26. Vogt, 10 (1883): 109-11, no. 702. On 10 December (1525), Dr. Sebastian von Fuchsstein to the Swabian League complains that on Corpus Christi of this year he was apprehended by the Burgomaster Mathes Clammer in his wife's own home ("uß was bösen aber doch meinthalb unverdinten wilen weis ich nit") and on instruction of the League was accused of inciting certain citizens to revolt. Shamed by this, he left the city, but was then invited back. He now seeks safe passage to attend the next diet of the League to answer for himself.

27. Jörg, 183.

28. The suggestion that Sacramentarian doctrine was uniquely communitarian, or that Anabaptist doctrine was uniquely rebellious, must be measured against a lack of evidence of direct theological influence in the southwest. Tom Scott, "Reformation and Peasants' War in Waldshut and Environs: A Structural Analysis," in Tom Scott, Town, Country, and Regions in Reformation Germany (Leiden: Brill, 2005), 3-56. Compare Heinrich R. Schmidt, “Die Häretisierung des Zwinglianismus im Reich seit 1525,” Zugänge zur bäuerlichen Reformation, 219-36.

29. Thomas A. Brady, Jr., Ruling Class, Regime and Reformation at Strasbourg, 1520-1555 (Leiden: Brill, 1978), 207. 
plundering soldiers brought a wave of refugees from nearby villages into Kaufbeuren. ${ }^{30}$ And so the aftermath of the war began.

\section{After the war}

The war ended about where it started, with the Swabian League encouraging the negotiation of peasant grievances. ${ }^{31}$ The outcome of the war was complex, and not immediately clear. Peasant losses were eased by expanding liberties in some territories, while liberties were lost in others, the princes in general walking away from the conflict much stronger than they were before. ${ }^{32}$ In the aftermath, numerous states, including the county of the Swabian League's Georg Truchsess von Waldburg, lord of a relatively large territory in the western Allgäu, reduced burdens on their peasants, conceding demands made during the war and negotiated by the survivors after it ended. ${ }^{33}$ The abbot of Kempten, whose refusal early that year to grant any peasant demands helped to unify the Allgäu rebels, also took a hard line after the peasant defeat. When negotiations in autumn faltered, the abbot ordered the knight Ulrich Schweikart and his deputies to arrest peasants in Obergünzburg, Thingau, Buchenberg, and Durach, which they did with evident pleasure, threatening and forcing peasants to watch as they smashed and plundered their homes. ${ }^{34}$

Ulrich Schweikart was Barbara's cousin, the son of her father's brother. He was now to become, as Barbara later said, "my greatest and most faithless enemy." ${ }^{35}$ An instrument of the abbot of Kempten's retribution, he and his

\section{Peter Blickle, Der Bauernjörg (Munich: C. H. Beck, 2015), 286.}

31. The Ten Articles formulated on 16 July 1525 at the Kohlenberg stipulated the conditions for the surrendered Allgäu army to return homage to overlords. They included a right for peasants to present grievances to the diets of the League. Otto Erhard, Der Bauernkrieg in der gefürsteten Grafschaft Kempten (Kempten and Munich: Joseph Kösel, 1909), 99.

32. Franz, 295-97.

33. Other states making concessions after the war included several lordships of the Upper Rhine; Zurich, Bern, St. Gallen, and Graubünden; the territory of Kempten, the Tyrol, Hesse, and Salzburg. Blickle, The Revolution of $1525,171-80$.

34. Scott and Scribner, eds., 209-312.

35. He is named as "iren vetter" in the affidavit Barbara received from the Memmingen city council 30 September 1528, attesting to the appointment of Hieronymus Hawser as her agent empowered to handle all aspects of her complaint against Ulrich before the Imperial Chamber Court. Munich, Bayerische 
deputies were soon threatening other families in the villages of the Allgau's fertile heartland: Reinhardsried, Obergünzburg, Albrechtsried, and Kraftisried. A woman in Reinhardsried was dragged from her sickbed and beaten with her husband and children. She died from her injuries. ${ }^{36}$ Meanwhile, the League was trying to get peasants and lords to negotiate. It formed a commission of six mediators at its 11 November diet and ordered the abbot again to wait for a settlement. The abbot would do no such thing. While peasants imprisoned by Ulrich languished in the Neuenburg, which was one of the abbot's small castles near Durach, signs of a rekindling rebellion appeared: anti-clerical incidents occurred at Betzigau and Buchenberg, and peasants at various places were withholding the payment of rents and fees. The cities of the Swabian League shepherded a treaty through the League's January 1526 diet, sealed by the cities of Memmingen and Kempten at the peasants' request, which required painful concessions from Abbot Sebastian von Breitenstein, regarding peasant marriages, taxes, protections against abuse by the abbot's officers, inheritance, and restrictions of movement. The treaty also confirmed a fine of twelve gulden payable to the abbot over twenty-four years beginning in 1530, with restoration of grain and silver and gold plate over a period of stipulated years (two and four, respectively). A six-gulden-per-household fine was payable to the League as compensation for the war.

The abbot ignored the treaty, imposing a raft of new taxes on fields and gardens, grain, hay, straw, and livestock. Further complaints brought matters to the League again in early 1527. In 1531, the peasants were still trying to keep their case alive, placing a collection of documents, including complaints

Hauptstaatsarchiv, Reichskammergericht, F 2141 Bestellnr 5500 (1), dated Memmingen 30 September 1528. Barbara's (undated) twenty-seven folio supplication to the Swabian League (1527 or 1528), which includes her account of the event, names him as "dem geblüt nach miner negsten gesupten vettern ainer, nemlich meins vatters brůders sune, aber der that halb an mir begangen mein hochster unnd unpetreuester veinde" (my next of kin by blood, namely, my father's brother's son, but my greatest and most faithless enemy on account of what he did to me). She identifies her father as Ulrich Schweikart the Elder. See Reichskammergericht F 2141 Bestellnr 5500 (46b), Barbara's petition to the Swabian League in twenty-seven folios: a first-person account, here $\mathrm{f}$. $1 \mathrm{r}$. The following narrative of the beginning of the conflict is based on folios $1 \mathrm{r}-4 \mathrm{v}$. An overview of the Imperial Chamber Court materials for the case is available in Bayerisches Hauptstaatsarchiv Reichskammergericht, 12 vols. to date, ed. B. Gebhardt, M. Horner, et al. (Munich: Generaldirektion der staatlichen Archive Bayerns, 1994-present), 9:432-33 no. 3698.

36. For this and the following, Erhard, 100-08. 
and treaties, in the care of Kempten's town council. ${ }^{37}$ And the residual conflict lingered well beyond the war.

This became Barbara's world. She claimed several of the villages that Ulrich Schweikart stole as her own fiefs: the one in Reinhardsried, four farmsteads at Eichelschwang, and property at Hauprechts, not to mention the castle of Westerried that Ulrich occupied..$^{38}$

Barbara first learned about Ulrich's intentions in late August of $1525,{ }^{39}$ on a Thursday, when the priest of the village of Aitrang, just west of Kaufbeuren, not far from the small Westerried castle, rode to her with a message from Ulrich. Ulrich said that because her paternal inheritance had been held in fief from the abbot of Kempten, there were questions about her mother's right and her own right to the estate, and that the Swabian League was going to sequester her property. Barbara told the messenger she had no worries about the Swabian League. Where exactly was her cousin, she wondered? She'd like to talk this over in person. The priest wouldn't say. So, Barbara sent a maid to track Ulrich down to a storehouse in Kaufbeuren. The maid asked Ulrich to come to Barbara. Ulrich said he would. He never did.

Then came a delegation of villagers, bringing new allegations to Barbara. "Utz Schweithart" had informed them that Barbara and her mother were now living with him in the Westerried castle, and they should pay him their rents and dues. When they told Ulrich they had never seen either woman there, he ordered them to render him homage, claiming that the abbot of Kempten had transferred Barbara's property to him.

So, Barbara rode off to Kempten, to lodge a complaint against Ulrich with the abbot. Passing by Westerried, Ulrich came out and met her on the road, inviting her to dismount and come inside. Sensing danger, she refused, and confronted him instead with the priest of Aitrang's report. Ulrich stood by his claim; the League wanted to seize her property, he said. In fact, one of their captains, "the Carver of Wangen," that is, Hans Schnitzer, the infantry captain of the Swabian League, was camped outside Kaufbeuren ready to despoil her house in the town. On what grounds, she asked? Her steward was a bad manager, he said. That, said Barbara, was news to her. Well, he broke some

37. Erhard, 100-08.

38. Bayerisches Hauptstaatsarchiv Reichskammergericht, 9:432-33 no. 3698.

39. The document is undated, but the reference to Hans Schnitzer suggests August 1525. 
things and devalued incomes, Ulrich replied, by Barbara's account (implicitly accusing the steward of joining the rebellion). Barbara later told the Swabian League, "I didn't believe my paternal inheritance should be taken from me on that account, nor could I believe that [Ulrich] was intending to act on his plan, since he never wanted to make fast and loose with my property before." ${ }^{40}$ No worries, Ulrich in effect told Barbara, he sent his servant to the steward to threaten him that Ulrich would personally lynch the steward if he damaged Schweikart property. Barbara noticed the ad hoc reasoning, pointing out that this was unfair to the steward and actually none of Ulrich's business.

She rode on to Kempten. The abbot received her graciously, then turned to his bailiff, Moritz von Altmaßhauen. Yes, Moritz reported, Ulrich had come, asking to be invested with her property, because the Swabian League threatened to take it, and her steward in Kaufbeuren had fled. Yes, the abbot granted his petition. For her part, Barbara reported the litany of Ulrich's abuses, how he acted in her name without her authorization. No, the abbot had assured her, he had no intention for Ulrich to do her injury. Yes, Barbara said, she was certain that her steward could explain why he left Kaufbeuren. No, she added, Ulrich was never authorized to act on her behalf.

But Abbot Sebastian von Breitenstein had no argument with Ulrich, and Barbara got nothing in Kempten. While Ulrich brought his case to the Imperial Aulic Council, which confirmed the abbot of Kempten's jurisdiction, Barbara appealed to the Swabian League and, with encouragement and support from the city council of Memmingen, to the Imperial Chamber Court (30 September 1528), reiterating her complaints with an affidavit from the city (5 February 1529) and winning a cease and desist order while the case was pending. ${ }^{41}$ The cease and desist order achieved nothing in itself. In 1529, Ulrich

40. Bayerisches Hauptstaatsarchiv Reichskammergericht, 9:432-33 no. 3698, f. 3r: "Unnd ich gelaubte nit das mir darumb mein vetterlich erb genomen solt werden. Ich konte auch nit gelauben, das er sollichs wie er sich berůmbte [sic] zů gůttem fourgenomen. Wann er hett doch dauor meines guts nie můsigstenn wollen.”

41. Munich, Bayerische Hauptstaatsarchiv (BHSA), Reichskammergericht, F 2141 Bestellnr 5500 (1). Ulrich responded by appointing his own agent and insisting that his claim to the lands she contested was entirely legitimate. BHSA Reichskammergericht, F 2141 Bestellnr 5500 (9). Her initial attorney, Hieronymus Hauser, was a doctor of laws and procurator at the Imperial Chamber Court (1524-39), who had studied in Wittenberg (as well as Ingolstadt and Freiburg) and who served as counsel for the city of Constance in conflicts with the bishop of Constance over incomes in the Thurgau. Anette Baumann, "Die Prokuratoren am Reichskammergericht in den ersten Jahrzehnten seines 
was still molesting Barbara's subjects, taking their rent, fees, eggs, hay, milk, etc., driving a villager named Michael Hefolin, with his wife and children, from their home, boasting that he now owned Barbara's forest, and had in fact won all her property, at the Imperial Aulic Council in Rottweil. ${ }^{42}$ Ulrich's lawyer made the same case again in April 1530, insisting on the abbot of Kempten's jurisdiction. Suddenly Ulrich's counsel introduced a new allegation, sputtering with bitter irony:

[...] a little while ago, an imperial edict went out everywhere, declaring that anyone belonging to the seductive Lutheran sect, and especially the Anabaptists, have relinquished all resources (mitell), their regalia, lordships, fiefs, and any other property. [...] the appellant [Barbara] is much reported [...] to have received "the love of God" and then "union with Christ our Lord in baptism" in such a manner, or better, in a pigheaded, unbelieving manner and intention, attaching herself to such a heretical rebaptism, and [she] not only let herself be baptized again, for a second time, but also provoked, seduced, [and] preached to others to do it, and administered such a heretical, bible-contradicting and illegal rebaptism herself. And the much-reported appellant herself may not deny it, insofar as such divine love and engrafting, a wonderful effect of the spirit of God in the baptism of one brotherhood, also contrary to longpraised and ancient Christian order and every ecclesiastical, temporal, imperial edict, finally determines that the appellant has no standing in this Imperial Chamber Court, [and her case] is not to be received, but rather once again, she has negated her claim to enfeoffed property, is responsible to the feudal lord indicated, according to feudal right, the matter to be

Bestehens," Das Reichskammergericht. Der Weg zu seiner Gründung und die ersten Jahrzehnte seines Wirkens (1451-1527), ed. Bernhard Diestelkamp (Cologne: Böhlau, 2003), 161-96, 191-92. BHSA Reichskammergericht F 2141 Bestellnr 5500 (10), Memmingen city council writes a brief note in support of Barbara von Fuchstein's appeal to the Imperial Chamber Court on 5 February 1529; presumably sent with Reichskammergericht F 2141 Bestellnr 5500 (10a), a document in which Barbara von Fuchstein née Schweikert, speaking in the first person singular in an undated document, complains that Ulrich is continuing to violate her property rights.

42. BHSA Reichskammergericht F 2141 Bestellnr 5500 (11) 5 July 1529: Barbara's lawyer to the Camerrichter, on Ulrich's violations since the Imperial Chamber Court's restraining orders of 30 October 1528 and 19 April 1529. Hauwser repeats the allegations in article 8 of thirteen articles rehearsing Ulrich's abuses to the court, on 7 January 1530. BHSA Reichskammergericht F 2141 Bestellnr 5500 (13). 
remitted there by your graces' judgement and right: so would the attorney ask the court to recognize, calling upon your graces and on justice. ${ }^{43}$

And the lawyer, Leopold Dickius, adds his name. It is noteworthy, and suspicious, that this allegation of heresy did not come up before. The court rejected Leopold's argument, saying that the abbot of Kempten did not in fact retain authority over the properties in question, as Schweikart's defense claimed, and the court attributed the allegations of Anabaptism to Barbara's deceased husband, Sebastian. Although the court granted that Anabaptism is truly horrendous and worthy of dispossession and death, the court's counsel noted that Ulrich had already taken possession before Barbara made her appeal, and before the imperial law dispossessing Anabaptists was issued. He could hardly try to dispossess her on those grounds now. ${ }^{44}$

43. BHSA Reichskammergericht F 2141 Bestellnr 5500 ([14a]=unnumbered item after 14) (the translation adds quotation marks to indicate this text's use of irony): Exceptiones contra appelationem des edlen und vesten Ulrichen Schweithard contra Barbaram Fuchstainerin, 4 April 1530. [...] "sagt anwaldt, das vorshiner zeÿdt, im heÿligen Romischen Reich allenthalben ain kay. offen edict ausgangen, das all die jenigen, so der verfurischen lutherischen sect, sonder der widerteuffern anhengig, an alle mitell, ire regalia, oberkhaiten, lehen oder andere ire gutter dardurch verwirckt haben. Zw dem auch im rechten undaupenlich $[s i c]$, wie allenthalben die recht heuffig dauon, und dan sollichs unsers allergnedigsten hern kay. mt. edict vermag weiter inhalts, So neben dem nit an, das gleuchwol vilgemelte appellierin, vergessen ir aid, lieb in got und dan ainigung in Christo unserm hern im tauff empffangen der gestaldt, gantz beser verstockter unglaubriger weiß und furnemens, solchen ketzerischen widertauff sich anhengig gemacht, und nit alain sich selbs widerumb und zwm andern mals teuffen lassen, sonder auch ander dazw geraitzt verfurt, gepredigt, und selbs solchern khetzerischen wider gotlich scrifft und alle recht, rebapthismum subministriert, selbs geteufft, das gleichwol vilgemelte appeliererin selbs in abredt nit sein mag, dieweil dan sollichs gottlicher lieb, und empflantzung wunderbarlicher wirckung durch den gaÿst gottes im tauff der bruderlichung ainig auch lang loblicher hergeprachter Cristenlicher ordnung allen geÿstlichen, weltlichen, kaÿserlichen edict zwwider, fliust schlieslich, uß disem, das die appelierin an disem kay. Camergericht nit stat, nach nit anzuonemen seÿ sonder abermals so sÿ ainich rechtuertigung oder zwspruch an gemelte seiner partheÿ, lehen gutter vorhaben vernaint, vor dem ernenten lehen herren zwthun, als lehens recht vermag, schuldig, durch E. G. mit urtell und recht dahin die sachen zwremittiern, das anwaldt also zwerkhennen gepeten haben will, E.G. und hilf der gerechtikhaÿdt diemitiglichen anruffendt, vorbehelthig, Leopold Dick. I." BHSA Reichskammergericht F 2141 Bestellnr 5500 (14b) is another copy of the same.

44. BHSA Reichskammergericht F 2141 Bestellnr 5500 (15) Responsiones et exceptiones respectiue in puncto attentatorum Ulrichen Schweÿdharten contra Barbaram Fuchstinerin, 2 May 1530: “[...] Habe er alle rents, zinß und gulten vor und nach, der appellacion eingenomen. Darumb mogen khaine attentata 
Barbara's response to Ulrich's latest ploy is surprising. She went to the city council of Memmingen and acquired a new affidavit. It claimed that Barbara had appeared before the council on Wednesday, 30 September 1528, to abjure Anabaptist heresy. The council wrote that,

when she was an ignorant woman, out of impressionability, she received the forbidden rebaptism before the prohibition went out, before it was known or understood that such was lawless or against Christian order, but she rather thought it truly Christian. As soon as she heard of the imperial mandate issued this year from Speyer on the fourth day of the month of January at Speyer and understood that such baptism was illegal, against imperial majesty, and against Christian order, as we have noted, so did she recant before us, crying and weeping, and witnessing before us her painful and heartfelt sorrow. ${ }^{45}$

The document, dated 30 September 1532, the fourth anniversary of Barbara's appeal, claims to rehearse events that occurred on the day of her appeal to the Imperial Chamber Court. The Imperial Regiment issued a mandate prescribing the death penalty for Anabaptism on 4 January 1528, three years after Barbara is said to have been rebaptized, and Memmingen followed suit with a gentler ordinance at the end of the month prohibiting Anabaptist

sollichs genent werden, anderst gesteet anwaldt disen vermainten funfften artickl nit. Dan (wie obstet) wo er das nit eingenomen hete die appellantin sein partheÿ sonder zweÿffels zw Rotweil nit beclagt."

45. BHSA Reichskammergericht F 2141 Bestellnr 5500 (24), Memmingen Rat to RKG in support of Barbara von Fuchstein, 30 sept 1528 (conclusion of text), while a note on the cover dates this as 30 Sept 1532: “[...] vor unns eröffnen und furpringen wiewol sÿ zuuersthiner zeit, alls ain unuerstenndig frawen bil, auß amfältigkait den uerpotten widertauft vor und es deshalbkam uerpott außganngen, noch das sÿ gewist und verstanden, das sollichs unrecht oder wider die cristenlich ornung seÿ, sonder vormaint damit recht cristenlich und wolgethan zuhaben angenomen so seÿ sÿ doch so bal sÿ außdem kayserlichen mandat ditz lauffenden jars auff den vierten tag des monats January zu Speyr außgangen gehört und uernomen das sollcher tauf im rechten verpotten, wider die keÿserlichen maiestat, und cristenlich ordnung seÿ, vonstundan, wie wir wissen kriegen dauon gestannden, den vor uns offenlich widerruofft, und sich mit wainonden augen geclegt, und vor uns bezeugt das ir sollchs schmertzlichs unnd hertzlichen laid, auch von uns darumb dem beruerten keyserlichen mandat geweß an leib und gutt gestrafft worden seÿe $[\ldots]$ ” 
residency and ordering any Anabaptists in the city to be expelled. ${ }^{46}$ Later that year, in December, a Memmingen urban assembly, with the help of Ambrosius Blaurer, prohibited the Mass. ${ }^{47}$ There is no indication of where or by whom she was baptized. The council assures the reader that it had physically and monetarily punished Barbara already, before "Utz Schwickher of Westerried" knew anything about her Anabaptism.

Maybe she had been an Anabaptist, and maybe she was not so sure what she was in 1525. An evangelical at the beginning of the Peasants' War was not the same thing as an evangelical in 1528 or 1532. The imperial laws against Anabaptism, a name for both wandering, dispossessed communes of re-baptizers and just about any severely anti-clerical opinion or outburst, had a marvellous filtering effect on the evangelical movement in the aftermath of the war. Like the charge of Sacramentarian heresy, it helped to begin the process of sorting out the de facto legitimacy of a protest against the Edict of Worms within the community of estates and the protesters' mounting violations of church property and personnel, while everyone agreed that "Anabaptists" should be dispossessed and in extreme cases killed. But in 1528, Barbara was sure she should not be considered an Anabaptist.

Soon after levelling the charge of heresy, Ulrich's meanness caught up with him. In 1531, a carpenter jailed at Augsburg for minting counterfeit money fingered Ulrich, who housed the operation in the Westerreid castle. Ferdinand of Austria ordered Ulrich's arrest. He was jailed in Kempten. The abbot Sebastian von Breitenstein tried to win his faithful servant's release. Instead, Ferdinand had Ulrich moved off to Innsbruck, where he languished for two years in jail, his case forgotten until nine relatives and friends petitioned the archduke for his release. ${ }^{48}$

46. For the mandate of the Imperial Regiment, see Gustav Bossert, ed., Herzogtum Württemberg (Quellen zur Geschichte der Wiedertäufer, 1; Quellen und Forschungen zur Reformationsgeschichte,

13) (Leipzig: M. Heinsius Nachfolger Eger und Sievers, 1930), $1^{*}-2^{*}$. Mecenseffy, ed., Österreich, 1. Teil, 61n1. This was not the 1529 law issued by the diet of Speyer, DRA 7:1325-27. For the Memmingen ordinance, see Friedrich Dobel, Memmingen im Reformationszeitalter nach handschjriftlichen und gleichzeitigen Quellen (Memmingen: Otto Besemfelder, 1877), 73.

47. Dobel, 70-71.

48. Johann Baptist Haggenmüller, Geschichte der Stadt und der gefürsteten Grafschaft Kempten von den ältesten Zeiten bis zu ihrer Vereinigung mit dem baierischen Staat, 2 vols. (Kempten: Tobias Pannheimer, 1847), 2:10-13. 
Barbara's lawyers continued to plead her suit against his claim to the family estate. ${ }^{49}$ The Imperial Chamber Court decided in her favour on 18 December 1536. Ulrich was forced to absolve the oaths he exacted from Barbara's serfs, that is, return them to her obedience, and hand over the Westerried castle, a confident woman's bloodless victory against a vicious kinsman.

Almost as soon as Barbara cleared her title to the contested lands, she sold most of them, including Westerried, to the abbot of Kempten, while the abbot confirmed her rights over the part she kept. ${ }^{50}$ Ulrich did the same with the pieces of his own estate that remained. Both transactions bear witness to the absorption of smaller holdings into larger principalities, the state-building trend once vaunted by Günter Franz as evidence of revolutionary failure and minimized by Peter Blickle in defense of the "revolution of the common man." ${ }^{51}$ Rather, the revolt fit "the local roots of political action" and helped even an imperial abbot show "greater respect for [...] subjects and vice versa," strengthening the intermediary role of local leaders, as Katherine Brun has observed. ${ }^{52}$ State-building in whatever dimension involved reciprocity between the commons and local government or lordship, such as Barbara Schweickert

49. Munich, BHSA Reichskammergericht F 2141 Bestellnr 5500 (20), Conclusiones Fraw Barbara von Fuchstain gebornen Schweitharcin gegen Ulrich Schwaithard, 14 Dec. 1532. Reichskammergericht F 2141 Bestellnr 5500 (21), Supplicatio per sequestratione ... Fraw Barbara von Fuchsstain geboren Schweythartin gegen Ulrichen Schweÿthart etc. 20 Nov. 1532. Reichskammergericht F 2141 Bestellnr 5500 (22), Conclusiones Excepcionales Ulrichen Schweitharten gegen Frawen Barbara Fuchsstainerin, 30 April 1532. Reichskammergericht F 2141 Bestellnr 5500 (23), Conclusiones contra partes aduersa conclusiones exceptionales Fuchssstainin contra Schwerthart, 30 Sept. 1532.

50. Staastarchiv Augsburg, Fürststift Kempten Urkunden 6399: Abt Wolffgang, Dechant und Konvent des Stifts Kempten versprechen Barbara Schweythartin, die ihnen den Weiler Aychelschwang, das Gut Haupprechts, den halben Maierhof zu Renhartzried und andere Stücke verkauft hat, daß sie die Urteilbriefe, die sie darüber gegen ihren Vetter Ulrich Schweythart zu Westerried am kaiserlichen Kammergericht erlangt hat, bei Bedarf ausleihen darf. — S 1: Abt Wolfgang, S 2: Konvent — "Am mittwoch den sechsundzwaynnzigsten tag des monats Junii” 1538.

51. Haggenmüller, Geschichte der Stadt, 2:10-13. Wolfgang von Grünenstein did not buy Westerried from Ulrich Schweikart "in the sixteenth century” as Anton Friderich Büsching once claimed; see A. F. Büsching, Neuer Erdbeschreibung des dritter Teils zweiter Band, welcher den schwäbischen, bayerischen, fränkischen und obersächsischen Kreis enthält (Hamburg: Carl Bohn, 1778), 47. See also Historischer Atlas von Bayern, Reihe 1: Schwaben, Heft 6: Kempten (http://geschichte.digitale-sammlungen.de/hab/ seite/bsb00008061_00147, accessed 29 July 2016), 130-31.

52. Katherine Brun, The Abbot and His Peasants: Territorial Formation in Salem from the Later Middle Ages to the Thirty Years War (Stuttgart: Lucius and Lucius, 2013), 158-59. 
evidently knew and her cousin Ulrich failed to understand, further testimony to the solidity of "a matrix of social-property relations which were still almost entirely feudal," even as commercialization of the rural economy steadily advanced. ${ }^{53}$

But the religious environment was proving to be less stable. For that reason, we should be cautious about conforming a woman like Barbara or her husband Sebastian to the labels some of their contemporaries tried to apply. It is important to approach religious identity from the vantage of a lifeworld dominated by material concerns, without expecting neat correlations or equivalences between the two. The power of the religious controversy ${ }^{54}$ unleashed by Martin Luther in everyday life is perhaps most keenly observable here, deep in the margins of religious debate, among people who were not lay preachers or priests or protagonists of the controversy themselves. ${ }^{55}$ In Nuremberg, Anna Hirschvogel, of the rich merchant family by that name, was destined to be celebrated as the first nun in Nuremberg to take a husband. As far as we know, she never once in her life expressed an opinion about evangelical doctrine, but found herself fighting for a share of her family's considerable estate after the Dominican convent of St. Catherine was closed. Anna appealed to, and won support from, Pope Clement VII and the Protestant council of Nuremberg at the same time. A group of Cistercian monks fled the cloister of Ebrach when it was raided by the peasants of Upper Franconia. They took refuge on monastery property in Schwabach, decided they liked it, got married, took over the parish, and for a while resisted the abbot's postwar attempts to regain control of his properties and the church in the town. And there was Barbara Schweickert, who may have admitted the crime of Anabaptism only to make unmistakably clear that she was no such thing. For many a bystander, the Reformation came home in conspiracies of events like those that engulfed her, a woman whose capacity matched and eventually overcame her violent kinsman-a person for whom contact with the religious controversy was secondary to, perhaps also inseparable from, family business.

53. Tom Scott, “The German Peasants' War and the 'Crisis of Feudalism,” Journal of Early Modern History 6 (2002): 265-95, republished in Scott, Early Reformation in Germany, 71-100, 89.

54. I speak deliberately of controversy, not reform. This is not a statement about Martin Luther's intentions but about the effect of religious controversy.

55. For this and the following, Ocker, "Between the Old Faith and the New," 235-39 (see note 2, above). 
